\title{
THE RÔLES OF NUCLEUS AND CYTOPLASM IN MELANIN ELABORATION
}

\author{
DAVENPORT HOOKER
}

From the Anatomical Laboratories of the Schools of Medicine of Yale University and the University of Pittsburgh

ONE FIGURE

The more recent work on the formation of melanin seeks to derive this pigment from chromatin elements. In 1889 Mertsching attributed the formation of melanin to the breaking down of the cell and especially to the destruction of the nucleus. Jarisch ('92) makes the statement, "Das Oberhautpigment entwickelt sich aus einer Kernsubstanz, dem Chromatin, oder einem diesem chemisch oder wenigstens räumlich nahe stehenden Körper." Rössle ('04), in the discussion of pigment formation in melanosarcomas, recognizes fives stages in the process, based on the appearance of the nucleus. He believes the melanin granules to be small particles of chromatin which are extruded from the nucleus, impoverishing the latter in the process.

Aurel von Szily ('11) has made a notable contribution to the theory of pigment formation from chromatic elements. $\mathrm{He}$ worked on the elaboration of melanin in developing eyes of a variety of vertebrates and in melanotic tumors of the human eye. According to his results, the melanin granules arise as colorless rod-like bodies (Pigmentträger) extruded from the nucleus, being derived directly from chromatic elements. These Pigmentträger are typical for species and locality of production. They also correspond exactly with the size and form of the melanin particles met with in that species and location. After being freed from the nucleus and wandering to a more or less peripheral position in the cell, the colorless Pigmentträger become colored probably by the action of cell ferments. The pigmentation of the Pigmentträger begins at one end of it and proceeds to the other. The origin of the Pigmentträger from the chromatin and their transition into the cell cytoplasm 
may be followed step by step. The nucleus which gives rise to them may be either productive or degenerative. In the former case, no impoverishment of the nucleus takes place; in the latter, pigment formation is accompanied by marked degenerative changes in the nucleus.

In 1910 Harrison presented evidence of a new type upon the question of pigment formation. In his paper on nerve growth in vitro, he mentioned and figured certain cells which became pigmented during the life of the cultures. To quote, Harrison found that "the pigment first arose as a round mass of granules lying just to one side of the nucleus. This (mass) gradually increased in size and then the pigment granules became scattered through the cytoplasm" ('10, p. 812).

In 1912, while working on the reactions to light of embryonic connective tissue melanophores, material for a careful study of the actual elaboration of the melanin granules themselves was found in the developing connective tissue and epithelial cells of embryos of Rana pipiens. For this study, Harrison plasma cultures, living embryos and serial sections of carefully fixed embryos were used. The development of the melanin was followed in embryos varying in length from 3 to $10 \mathrm{~mm}$.

Though the melanophoric cells found in the epidermis of older frog larvae are certainly mesodermal in origin, many ectodermal cells of young embryos elaborate this pigment within themselves. The pigment, however, after existing for a time in the cells, gradually disappears. That connective tissue cells elaborate melanin has long been an established fact. The mode of its development in these two types of cells is the same.

Plasma cultures. Small pieces of mesenchyme and epithelium from Rana pipiens embryos 3 to $4 \mathrm{~mm}$. long were implanted in the plasma of frogs of varying species. Seventeen primary cultures were made. These lived in good condition over periods varying from three to forty days. In the case of the older cultures, the plasma was changed at frequent intervals. From these primary cultures, secondary were made, to the number of sixteen, by removing fragments of tissue and reimplanting in new plasma. In all, thirty-three cultures were studied.

At first (fig. 1, A) the cells were clear and translucent, without 


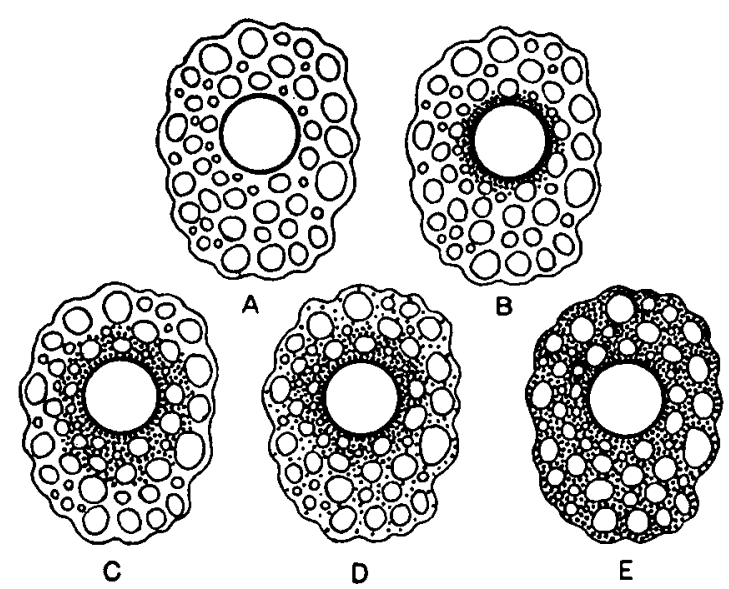

Fig. 1 Diagrammatic sketch to show the different stages of melanin elaboration. The heavily outlined circle in the center represents the nucleus of the cell, the smaller ovals represent oil droplets. The cell is represented in median section.

pigment granules, but contained fat droplets scattered throughout the cytoplasm and a more or less centrally placed nucleus. Then a few small, spherical, brownish granules became visible in the cytoplasm of the cell immediately adjacent to the nucleus, appearing simultaneously, or nearly so, on all sides of it. Their number gradually increased until a well defined hollow sphere surrounded the nucleus (fig. 1, B). On their first appearance, these melanin granules presented all the characteristics which are normal for them. No positive evidence of any increase in size of the individual particles of pigment was obtained. Owing, however, to their minuteness, an accurate determination of any such change presents almost insurmountable difficulties.

No granules made their appearance at any time inside the nuclear membrane nor in the cytoplasm of the cell away from the nucleus. The region of production was limited to that zone of the cytoplasm which is in contact with the nucleus. Nor was there any sign of the presence of colorless granules, which, by a process of pigmentation, could be transformed into the particles of melanin. The most careful search for any morphological structure within the cell that might serve as a Pigmentträger in von Szily's sense, was unavailing.

With each succeeding day, the number of melanin granules 
increased. During the earlier stages of this process, they remained concentrated in the center of the cell, the periphery of the cloud of densely packed granules becoming larger and further away from the nucleus (fig. 1, C). Then the granules began to spread throughout the cell. This process was gradual and was accomplished by the slow separation of the individual elements of the dense cloud about the nucleus. At first, but a few granules, widely separated from one another, detached themselves from the central mass and wandered among the oil droplets nearest at hand. As this process of distribution, accompanied by further production of new granules around the nucleus, continued, more and more of the pigment particles spread toward the periphery (fig. 1, D), in such a manner that the number of granules per unit area steadily decreased from within outward. The periphery of the cell always contained fewer granules than the center until the final stage of melanin elaboration was reached (fig. 1, E). At this time, the cytoplasm of the cell was filled, one might say, to 'saturation.' 'Through this cloud of granules, the fat droplets and the nucleus were visible as clear, translucent areas, absolutely free from pigment. The entire process here described is completed in a period of eight to fourteen days, on an average.

Living embryos. By carefully dissecting out scraps of mesenchyme and epidermis from embryos of different ages and mounting them in plasma or isotonic saline ( 0.4 per cent), the different stages of melanin elaboration may be observed. That the steps thus seen are not continuous, but isolated from one another, is true. This objection to the method is obviated, however, by the check provided by the cultures. Every step in the elaboration of melanin observed in the cultures is exactly duplicated in the normal body. The light brown granules of melanin are found, at first, only in the region of the nucleus and then spread through the cytoplasm of the cell. They are colored on their first appearance, a fact which seems clearly to do away with the colorless Pigmentträger idea.

Serial sections. Like the study of fresh material from living embryos, that of serial sections serves principally as a check upon the cultures. A description of the findings here would 
be but a repetition of facts already stated, with one important exception. The most minute examination of series fixed in all stages of melanin formation fails to show the slightest change in character and content or the least sign of degeneration or depletion in the nucleus. Nor can any evidence be found to show that the nucleus plays a part in the formation of melanin by a process of extrusion of any of its elements into the cytoplasm. All the granules of pigment are found in the cytoplasm near the nucleus, but they have no visible, structural connection with the nucleus or any of its contents.

Certain very important objections to the chromatin idea of the origin of melanin are evident from the results set forth above.

The nuclei of the pigment-forming cells suffer no depletion during the process Though von Szily claims that certain nuclei which he terms 'active,' develop pigment without loss to their content, the actual depletion of many others was also seen by him. Rössle describes minutely many changes which occur in the nucleus and states that after the extrusion of chromatin to form melanin, the nucleus is bladderlike, with a reduced amount of chromatin.

No colorless anlagen for the melanin granules are to be found in the form of 'Pigmentträger' (v. Szily, '11) or 'Pigmentbildner' (Fischel, '96). That a chemical anlage in the form of a chromogen is present is almost certain in view of the work of Bertrand ('08) but that the melanogen exists in the frog as a definite morphological structure, which, without any other change than in its coloration, becomes the pigment granule itself, may be denied.

The process of pigmentation of a melanophore in the frog begins in the area nearest the nucleus and spreads from that point throughout the cell, that is to say, it progresses from the center of the cell to the periphery. This is in direct opposition to the observations of von Szily, who states that the pigmentation of the colorless Pigmentträger takes place gradually while they are wandering about in the cytoplasm. Indeed, his figure 4 (plate 4) shows the process going on irregularly throughout the cell and figure 8 of the same plate illustrates a process directly the reverse of that noted in this paper, namely, the appearance 
of pigmented granules at the periphery of the cell before they are present near the nucleus.

The last, and probably the most important, objection to the supposed chromatin origin of melanin granules is the fact that no process of extrusion of chromatin nor any of the steps of such a process are to be observed. The pigment granules appear near the nucleus, in fact, in almost direct apposition to the nucleus, but no evidence was found in this work which even suggests a morphological relationship to either the nucleus or its contents.

It may safely be concluded that, in the normal ontogenetic origin of melanin in the frog, the chromatin plays no direct rôle. On the contrary, all the evidence obtained goes to demonstrate that the melanin granules are formed in the cytoplasm, from elements already present in solution in it, through some action of the nucleus.

Bertrand ('96) isolated an enzyme in plants (Russula and Dahlia) which, by its oxidizing action on tyrosin, was named tyrosinase. Von Fürth and Schneider ('01) found this same ferment in the haemolymph of Lepidopteran larvae and noted its occurrence in many animal forms. The action of this enzyme on tyrosin gives a melanin and von Fürth suggested,

. . . . dass die physiologische Bildung melaninartiger Pigmente in den tierischen Geweben auf das Zusammenwirken von zweierlei Fermenten zurückzuführen sei: durch ein autolytisclies Ferment könnte ein aromatischer Komplex aus dem Eiweismaterial abgespalten und dieser sodann durch eine Tyrosinase in ein Melanin übergeführt werden. $\left(1901\right.$, p. 242). ${ }^{1}$

The remarkable results of Bertrand's ('08) more recent work demonstrate the manner in which tyrosin and its derivatives may form the various types of the melanins usually met with in the animal body. He determined that many substances may be transformed into melanin by the oxidizing action of tyrosinase, each giving a characteristic color. During oxidation, a play of colors results, the earlier stages of the process giving lighter colors than the more advanced. The essential constitu-

${ }^{1}$ It is not within the province of this paper to review in detail the literature on the melanins. The reader is referred to the excellent Sammelreferat of von Fürth ('04). 
ent seems to be a benzene ring with an hydroxyl radicle. Tyrosin itself gives a black pigment, while paraoxyphenylacetic and paraoxyphenylpropionic acids give browns. It should be remembered, however, that the individual granules of 'black' melanin are brown; those of 'brown' melanins, yellowish in color. ${ }^{2}$

Gessard ('03) has given the strongest evidence yet adduced for the actual formation of melanin in the animal body from tyrosin. Working on melanotic tumors in horses, he determined the presence of free tyrosin and adds: "La tyrosine est donc le chromogene dont l'oxidation par la tyrosinase détermine la formation du pigment noir commun à divers produits physiologiques et pathologiques de l'économie animal." (p. 1088).

The recent work on protein digestion demonstrates that aminoacids are absorbed, unchanged, by the blood stream from the alimentary canal and are distributed to the tissues (Folin, '14). Van Slyke and Meyer ('13) have shown that "the disappearance of intravenously injected amino-acids from the circulation is the result of neither their destruction, synthesis nor chemical incorporation into cell proteins. The acids are merely absorbed from the blood by the tissues, without undergoing any immediate chemical change." They have also demonstrated that there is a limit to the amount of amino-acids that may be absorbed by the tissues, so that a certain equilibrium exists between the blood and the tissues so far as the amino-acids are concerned. Further, Osborne and Mendel ('12) have shown that, while certain amino-acid groups will sustain life if fed as an exclusive diet, "on the other hand it is clear that when certain aminoacid groups are lacking, nutritive equilibrium is impossible. The cyclic derivatives, lyrosin and tryptophane, appear to be included here" (p. 326).

Several of the protein putrefaction products mentioned by Bertrand as sources of melanin, as paracresol, paraoxyphenylacetic acid and others, all derivatives of tyrosin, also are known to be absorbed as such by the organism. There can be but little doubt that sufficient quantities of melanin-forming substances occur normally in the body.

${ }^{2} \mathrm{H}$. Eppinger ('10) isolated a melanogen from the urine of patients suffering from melanosarcoma which turned black on oxidation. This he believes to be derived, not from a tyrosin base, but from tryptophane. 
J. Loeb has repeatedly made the statement that oxidation is a prominent function of the nucleus in normal development and regeneration. Perhaps the most striking proof of this fact in specific tissues in the adult has been given by the work of $R$. S. Lillie ('02). By soaking thin slices of living tissues in solutions of substances which, colorless in the unoxidized condition, give brilliant color reactions on oxidation, he was able to determine the exact location in the individual cell where this reaction proceeds to the greatest extent. His findings "furnish, it is believed, conclusive evidence that in many tissues the nucleus is the chief agency in the intracellular activation of oxygen; and, further, that the active or atomic oxygen is in general most abundantly freed at the surface of contact between nucleus and cytoplasm" ('02, p. 420).

The findings in the normal development of melanin in the embryonic frog furnish strong histological evidence that the nucleus of the cells elaborating this pigment provides something vitally necessary for its production. The melanin granules appear, not in haphazard manner throughout the cell, but in the cytoplasm immediately about the nucleus or, in Lillie's words, "at the surface of contact between nucleus and cytoplasm." Lillie's work seems to indicate clearly that the vitally necessary element for melanin elaboration provided by the nucleus is an oxidizer. Jaquet in 1892 demonstrated that the oxidizing action of the cell was not alone a property of living tissue, but was also evinced by broken-down cells which were no longer living. Nevertheless, the oxidases present in dead cells were originally elaborated by the nucleus. Lillie's work demonstrates this.

The particular form which the oxidizing action of the nucleus takes in melanin elaboration is that of an oxidase, perhaps of a type of tyrosinase. A host of investigators, following in the footsteps of Bertrand's ('96) original discovery of the presence of tyrosinase in plants, have isolated this enzyme in many animal forms and in such bodily positions as to serve normally for the manufacture of melanin.

The data derived from these various sources may be briefly suinmed up as follows:

1. Tyrosin, or its derivatives, acted upon by an oxidizing 
agent, tyrosinase, gives a melanin. (Bertrand, '96 and '08; von Fürth and Schneider, '01, etc.)

2. Free tyrosin was discovered by Gessard ('03) in horses with melanotic tumors and it is now a well known fact that derivatives of tyrosin are absorbed by the animal body.

3. Lillie ('02) gave definite proof of the rôle played by the nucleus as a producer of oxygen or of an oxidase.

4. The normal presence of tyrosinase discovered in many parts of the body by Gessard ('01, '02, '03,) Przibram ('01), ${ }^{3}$ Dewitz ('02), Durham ('04), Weindl ('07), etc.

When the histological data presented in this paper are considered in connection with the facts just reviewed, it will be seen that they are in full accord with one another. While no evidence has been obtained from this work that tyrosin is present in the cells under consideration, it is shown that the base from which the melanin granules are formed probably exists in a soluble condition in the cytoplasm. The rôle of the cytoplasm, then, is that of a carrier of the chromogen. That the nucleus plays an all important rôle is evident.

\section{CONCLUSIONS}

It is felt that the evidence here brought forward demonstrates conclusively the following points:

1. That the theory of the origin of melanin from chromatin elements extruded from the nucleus into the cytoplasm is untenable, at least in the frog.

2. That, however, the nucleus plays an essential part in pigment formation by some activity which greatly resembles an oxidizing action.

3. That melanin is formed in the cytoplasm of the cell at the point of known greatest efficiency of the nucleus as an oxidizing agent.

The following general conclusion from these facts seems justified: that, in the cells of embryo frogs, melanin is formed from some substance (probably tyrosin or its derivatives) in solution in the cytoplasm when acted upon by the nucleus (perhaps an oxidase reaction).

Anatomical Laboratory, University of Pittsburgh

3 Evidence given by von Fürth and Schneider ('01, p. 241). 


\section{LITERATURE CITED}

Bertrand, G. 1896 Sur une nouvelle oxydase ou ferment soluble oxydant d'origine végétale. Compt. rend. de l'Acad. d. Sci., tom. 122, p. 1215. 1908 Recherches sur la mélanogénesis: Action de la tyrosinase sur la tyrosine. Ann. de l'Inst. Pasteur, tom. 22, p, 381.

Dewitz, J. 1902 Recherches experimentales sur la métamorphose des insectes. Compt. rend. d. 1. Soc. Biol., tom. 54, p. 44.

DURHAM, F. 1904 On the presence of tyrosinase in the skins of some pigmented vertebrates. Proc. R. S. London, vol. 74.

Eppinger, H. 1910 ther Melanurie. Biochem. Zeitschr., Bd. 28, p. 181.

Fischel, A. 1896 Über Beeinflussung und Entwicklung des Pigmentes. Arch. f. mikr. Anat., Bd. 47, p. 719.

Folin, O. 1914 Intermediary protein metabolism. Jour. A. M. A., Vol. 63, p. 823.

voN FƯRTH, O. 1904 Physiologische und chemische Untersuchungen über melanotische Pigmente. (Sammelreferat). Centralbl. f. allg. Path. u. path. Anat., Bd. 15, p. 617.

von FÜrth, O. UND Schneider, H. 1901 tber tierische Tyrosinasen und ihre Beziehung zur Pigmentbildung. Hofmeister's Beiträge $z$. chem. Physiol. u. Path., Bd. 1, p. 229, 1901-02.

Gessard, C. 1901 Etudes sur la tyrosinase. Ann. de l'Inst. Pasteur, tom. 15 , p. 593.

1902 Tyrosinase animale. Compt. rend. d. l. Soc. Biol., tom. 54, p. 1304.

1903 Sur la formation du pigment mélanique dans les tumeurs du cheval. Compt. rend. d. l. Soc. Biol., tom. 136, p. 1086.

Harrison, R. G. 1910 The outgrowth of the nerve fiber as a form of protoplasmic movement. Jour. Exp. Zoöl., vol. 9, p. 787.

Jarisce 1892 Uber die Bildung des Pigmentes in den Oberhautzellen. Arch. f. Dermat. u. Syphlis, Bd. 23, p. 223.

LILLIE, R. S. 1902 On the oxidative properties of the cell nucleus. Am. Journ. Physiol., vol. 7, p. 412.

Mertsching 1889 Histologische Studien über Keratohyalin und Pigment. Virchow's Arch., Bd. 116, p. 484.

Osborne, T. B. and Mendel, L. B. 1914 Amino-acids in nutrition and growth. Jour. Biol. Chem., Vol. 17, p. 325.

Rössle, R. 1904 Die Pigmentierungvorgang in Melanosarkom. Zeitschr. f. Krebsforschung, Bd. 2, p. 291.

VAN SLYKe, D. D. and MEYer, G. M. 1913 The fate of protein digestion products in the body. III. The absorption of amino-acids from the blood by the tissues. Jour. Biol. Chem., Vol. 16, p. 197.

voN Szily, A. 1911 Utber die Entstehung des melanotischen Pigmentes im Auge der Wirbeltierembryonen und in Chorioidealsarkomen. Arch. f. mikr. Anat., Bd. 77, p. 87.

Weinde, T. 1907 Pigmententstehung auf Grund vorgebildeter Tyrosinasen. Arch. f. Entw-mech., Bd. 23, p. 632. 